\title{
Crystal structure and spectroscopic study of bis-tetrapropylammonium hexachlorodicuprate(II), $\left[\mathrm{N}\left(\mathrm{C}_{3} \mathrm{H}_{7}\right)_{4}\right]_{2} \mathrm{Cu}_{2} \mathrm{Cl}_{6}$
}

\author{
Ikram Dhouib a,*, Philippe Guionneau b, Stanislav Pechev b, Tahar Mhiri a and Zakaria Elaoud a \\ a Laboratoire de Physico-Chimie de l'Etat Solide, Département de Chimie, Faculté des Sciences de Sfax, Université de Sfax, Sfax 3000, Tunisie \\ b CNRS, Université de Bordeaux, ICMCB, 87 avenue du Dr A. Schweitzer, Pessac, F-33608, France \\ *Corresponding author at: Laboratoire de Physico-Chimie de l'Etat Solide, Département de Chimie, Faculté des Sciences de Sfax, Université de Sfax, Sfax 3000, \\ Tunisie. Tel.: +2.169.7019206; fax: +2.167.4274437. E-mail address: ikramdhouib82@yahoo.fr (I. Dhouib).
}

\section{ARTICLE INFORMATION}

Received: 17 January 2013

Accepted: 23 January 2013

Online: 30 June 2013

\section{KEYWORDS}

Single crystal

Copper(II) complex

Spectroscopic study

Tetrapropylammonium

Hexachlorodicuprate(II)

Crystal structure analysis

\begin{abstract}

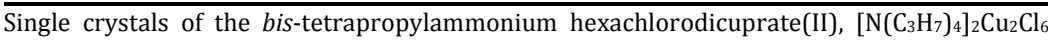
were grown by slow evaporation solution technique at room temperature. The compound was characterized by Raman, IR and single crystal X-ray diffraction studies. Crystal data for $\mathrm{C}_{12} \mathrm{H}_{28} \mathrm{Cl}_{3} \mathrm{CuN}(\mathrm{M}=356.24 \mathrm{~g} / \mathrm{mol})$ : triclinic, space group P-1 (no. 2), $a=9.3851(2) \AA, b=$ 9.3844(2) $\AA, c=11.8837(3) \AA, \alpha=106.3330(11)^{\circ}, \beta=100.0280(12)^{\circ}, \gamma=113.2830(12)^{\circ}, V=$ $872.95(3) \AA^{3}, Z=2, T=293(2) \mathrm{K}, \mu\left(\mathrm{MoK}_{\alpha}\right)=1.693 \mathrm{~mm}^{-1}, D_{\text {calc }}=1.355 \mathrm{~g} / \mathrm{mm}^{3}, 8056$ reflections measured $(6.64 \leq 2 \Theta \leq 62.02), 5526$ unique $\left(R_{\text {int }}=0.0303\right)$ which were used in all calculations. The final $R_{1}$ was $0.0427\left(>2 \sigma(\mathrm{I})\right.$ ) and $w R_{2}$ was 0.1312 (all data). The atomic arrangement can be described by alternating organic and inorganic layers parallel to the (101) plan, made up of tetrapropylammonium groups and $\mathrm{Cu}_{2} \mathrm{Cl}_{6}$ dimers, respectively. In crystal structure, the inorganic layers, built up by $\mathrm{Cu}_{2} \mathrm{Cl}_{6}$ dimers, are connected to the organic ones through hydrogen bonding $\mathrm{C}-\mathrm{H}$...Cl and Van der Waals interaction in order to build cation-anion-cation cohesion. These interactions cause to the formation of a three-dimensional supramolecular architecture.
\end{abstract}

\section{Introduction}

The combination of organic molecules and inorganic materials was the starting point for the development of new hybrid compounds, with expected physical and chemical properties. These compounds have attracted great attention because of their unique opportunity to combine the remarkable features of organic compounds with those of inorganic materials. Their applications have been explored and reported in various fields, such as magnetism, conductive, luminescence and optical properties [1-5]. The materials based upon substituted complex ammoniums with halogenated metals such as $\mathrm{Hg}, \mathrm{Cd}, \mathrm{Zn}, \mathrm{Mn}$ and $\mathrm{Cu}$ etc. present very interesting physical properties [6-12].

The large structural variability of copper(II) due to the presence of an active Jahn-Teller effect in the $d^{9}$ electronic system and the relative flatness of the potential surfaces make the thermochromism in chlorocuprates of continual interest. These compounds and their properties are of interest not only in inorganic chemistry but also in fields ranging from solidstate physics to bioinorganic chemistry. Among solid-state physicists and chemists, there is a great interest in the copper(II) halides owing to the plasticity of the metal coordination sphere which leads to a great variety of crystalline architectures with different coordination numbers, geometries and nuclearities, and makes copper systems as excellent candidates for analysing correlations between structural parameters and magnetic properties [13-17].

On the other hand, compounds crystallized with aliphatic tetra-ammonium cations with general formula $\left(\mathrm{C}_{n} \mathrm{H}_{2 n+1}\right)_{4} \mathrm{~N}^{+}$, such as $\left(\mathrm{CH}_{3}\right)_{4} \mathrm{~N}^{+}, \quad\left(\mathrm{C}_{2} \mathrm{H}_{5}\right)_{4} \mathrm{~N}^{+},\left(\mathrm{C}_{3} \mathrm{H}_{7}\right)_{4} \mathrm{~N}^{+}$, undergo many structural phase transitions governed by the reorientational dynamics of the tetra-alkyl-ammonium groups $[10,12,18]$. In fact, a variety of compounds are formed by the reaction of mixed tetra-alkyl-ammonium with halogenated metals where $\mathrm{n}$ $\leq 2$. Furthermore, the crystalline structure of these derivate can be described as a sequence of alternating layers of $\mathrm{MX}_{4}$ tetrahedra; the organic chains are inserted between these sheets.

The $\mathrm{Cu}_{2} \mathrm{Cl}_{6}{ }^{2-}$ polyhedra can be described as two distorted tetrahedrons composed of two groups of $\mathrm{CuCl}_{4}$ tetrahedra sharing two chlorines with a symmetry center in between. It accounts for the synthesis, the structural characterization by Xray diffraction, IR and Raman spectroscopy of the bistetrapropylammonuim hexachlorodicuprate(II), $\left[\mathrm{N}\left(\mathrm{C}_{3} \mathrm{H}_{7}\right)_{4}\right]_{2}$ $\mathrm{Cu}_{2} \mathrm{Cl}_{6}$.

\section{Experimental}

\subsection{Synthesis}

The title compound was prepared by mixing $\left(\mathrm{CH}_{3} \mathrm{CH}_{2} \mathrm{CH}_{2}\right)_{4} \mathrm{NOH} \quad(1 \mathrm{mmol}), \quad \mathrm{CuCl}_{2} .2 \mathrm{H}_{2} \mathrm{O} \quad(2 \mathrm{mmol})$ concentrated $\mathrm{HCl}(1 \mathrm{~mL})$ and water $(10 \mathrm{~mL})$. The mixture was then allowed to stand and evaporate slowly at room temperature. After 3 days, brown crystals appeared and they were studied by single crystal X-ray diffraction. The analysis of the obtained phase confirms the formation of

\subsection{Characterizations}

The infrared spectrum was recorded in the range 700-4000 $\mathrm{cm}^{-1}$ with a "Perkin Elmer FTIR-1000" spectrophotometer using a sample dispersed in a $\mathrm{KBr}$ pellet. $\left[\left(\mathrm{CH}_{3} \mathrm{CH}_{2} \mathrm{CH}_{2}\right)_{4} \mathrm{~N}\right]_{2} \mathrm{Cu}_{2} \mathrm{Cl}_{6}$. 


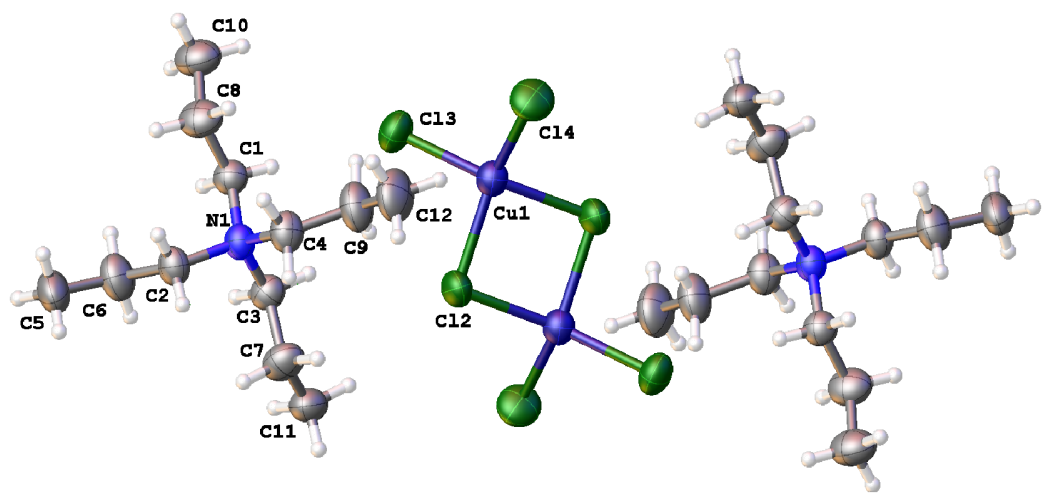

Figure 1. The asymmetric unit of $\left[\left(\mathrm{CH}_{3} \mathrm{CH}_{2} \mathrm{CH}_{2}\right)_{4} \mathrm{~N}\right]_{2} \mathrm{Cu}_{2} \mathrm{Cl}_{6}$.

Back scattering Raman spectra were obtained under microscope with a T-64000 Raman spectrometer (ISA, Jobin Yvon) in the $50-4050 \mathrm{~cm}^{-1}$ range.

\subsection{X-ray single crystal structure determination}

Single crystal X-ray diffraction data of the title compound were collected at room temperature on a Nonius Kappa-CCD diffractometer using Mo-Ko radiation $(\lambda=0.71073 \AA)$ through the program COLLECT [19]. Correction for Lorentz-polarisation effect, peak integration and background determination were carried out with the program DENZO [20]. Frame scaling and unit cell parameters refinement were performed with the program SCALEPACK [20].

Pertinent details of the crystal structure of $\left[\left(\mathrm{CH}_{3} \mathrm{CH}_{2} \mathrm{CH}_{2}\right)_{4} \mathrm{~N}\right]_{2} \mathrm{Cu}_{2} \mathrm{Cl}_{6}$ are listed in Table 1 . The crystal structure has been solved and refined in the triclinic symmetry, space group $P$-1, using the WINGX environment [21] and based on SHELXS97 [22] and SHELXL97 [23]. All the hydrogen positions of the diprotonated cation were placed geometrically and held in the riding mode. The $\mathrm{C}-\mathrm{H}$ bonds were fixed and affined at 0.76 and $1.05 \AA$. Bond distances and angles calculated from the final atomic coordinates, as well as probable hydrogen bonds, are given in Table 2 and 3, respectively.

\begin{tabular}{|c|c|}
\hline Empirical formula & $\mathrm{C}_{12} \mathrm{H}_{28} \mathrm{Cl}_{3} \mathrm{CuN}$ \\
\hline Formula weight, $\mathrm{g} / \mathrm{mol}$ & 356.24 \\
\hline Color & Brown \\
\hline Temperature, $\mathrm{K}$ & $293(2)$ \\
\hline Crystal system & Triclinic \\
\hline Space group & P-1 \\
\hline a, $\AA$ & $9.3851(2)$ \\
\hline $\mathrm{b}, \AA$ & $9.3844(2)$ \\
\hline c, $\AA$ & $11.8837(3)$ \\
\hline$\alpha,{ }^{\circ}$ & $106.3330(11)$ \\
\hline$\beta,{ }^{\circ}$ & $100.0280(12)$ \\
\hline$\gamma{ }^{\circ}$ & $113.2830(12)$ \\
\hline Volume, $\AA^{3}$ & $872.95(3)$ \\
\hline $\mathrm{Z}$ & 2 \\
\hline$\rho_{\text {calc }}, \mathrm{mg} / \mathrm{mm}^{3}$ & 1.355 \\
\hline$\mu, \mathrm{mm}^{-1}$ & 1.693 \\
\hline $\mathrm{F}(000)$ & 374.0 \\
\hline Diffractometer/scan & KAPPA CCD. Enraf-Nonius \\
\hline $\begin{array}{l}\text { Radiation, graphite } \\
\text { monochromater }\end{array}$ & Mo $K \alpha(\lambda=0.71073 \AA)$ \\
\hline Crystal size, $\mathrm{mm}^{3}$ & $0.2 \times 0.2 \times 0.12$ \\
\hline $2 \Theta$ range for data collection & 6.64 to $62.02^{\circ}$ \\
\hline Index ranges & $-13 \leq h \leq 13,-13 \leq k \leq 13,-17 \leq l \leq 17$ \\
\hline Reflections collected & 8056 \\
\hline Independent reflections & $5526[\mathrm{R}(\mathrm{int})=0.0303]$ \\
\hline Data/restraints/parameters & $5526 / 0 / 194$ \\
\hline Goodness-of-fit on $\mathrm{F}^{2}$ & 1.046 \\
\hline Final $R$ indexes $[\mathrm{I}>=2 \sigma(\mathrm{I})]$ & $\mathrm{R}_{1}=0.0427, \mathrm{wR}_{2}=0.1208$ \\
\hline Final R indexes [all data] & $\mathrm{R}_{1}=0.0589, \mathrm{wR}_{2}=0.1312$ \\
\hline Largest diff. peak/hole, e $\AA^{-3}$ & $0.76 /-0.63$ \\
\hline
\end{tabular}

\section{Results and discussion}

\subsection{Structural analysis}

The asymmetric unit is composed of half $\left[\mathrm{Cu}_{2} \mathrm{Cl}_{6}\right]^{2-}$ anion and one $\left[\left(\mathrm{CH}_{3} \mathrm{CH}_{2} \mathrm{CH}_{2}\right)_{4} \mathrm{~N}\right]^{+}$cation (Figure 1). The $\mathrm{Cu}-\mathrm{Cl}$ distances are about similar (Table 2). The $\mathrm{Cu}-\mathrm{Cl}$ bond distances are in the range of 2.2046(6)-2.3231(6) $\AA$ for the $\mathrm{Cu}_{2} \mathrm{Cl}_{6}{ }^{2-}$ anion. These bond distances fall in the range reported previously for compounds containing $\mathrm{Cu}-\mathrm{Cl}$ bonds [24-28]. The $\mathrm{Cl}-\mathrm{Cu}-\mathrm{Cl}$ angles are present in two distinguished sets. The first contains four angles of 96.31(2) and 147.66(3) ${ }^{\circ}$ which are much lower than the other set which contains two angles of 97.20(3) and $146.13(3)^{\circ}$. These distortions are typically measured by the value of the mean trans and cis-Cl-Cu-Cl angle, which is 146.895 $\circ$ and $97.366^{\circ}$, respectively. Accordingly the geometry of $\mathrm{Cu}_{2} \mathrm{Cl}_{6}{ }^{2-}$ anion is highly distorted around the $\mathrm{Cu}(\mathrm{II})$ ion, which in fact, is always distorted. The coordination about each copper is intermediate between a planar and a tetrahedral arrangement of four chlorine ligands, $\mathrm{Cu}(1)-\mathrm{Cl}(2)$ (2.3152(6) Å) [29]. The principal feature of the crystal structure is the existence of essentially isolated $\left[\mathrm{Cu}_{2} \mathrm{Cl}_{6}\right]^{2-}$ dimmers with a copper-chlorinecopper angle of $94.45(2)^{\circ}$. By space group symmetry requirements, the dimers have only a centre of symmetry connects the respective equivalent pairs of $\mathrm{Cu}(1), \mathrm{Cl}(2), \mathrm{Cl}(3)$ and $\mathrm{Cl}(4)$. The copper-copper separation in the dimer is in the value of $3.405 \AA$. The structural arrangement of $\left[\mathrm{N}\left(\mathrm{C}_{3} \mathrm{H}_{7}\right)_{4}\right]_{2} \mathrm{Cu}_{2} \mathrm{Cl}_{6}$ can be described as an alternation of organic $\left[\mathrm{N}\left(\mathrm{C}_{3} \mathrm{H}_{7}\right)_{4}\right]^{+}$groups and inorganic $\mathrm{Cu}_{2} \mathrm{Cl}_{6}$ dimers (Figure 2 ).

The lengths of the $\mathrm{N}-\mathrm{C}$ bonds are in the range between $1.518(2)$ and 1.526(3) $\AA$. The $\mathrm{C}-\mathrm{N}-\mathrm{C}$ angles range from $105.15(15)$ to $111.77(16)^{\circ}$. The C-C bonds lengths are in the region between 1.495(4) and 1.521(3) Å. In these layers each $\left[\mathrm{Cu}_{2} \mathrm{Cl}_{6}\right]^{2-}$ anion is interacting with ten surrounding cations via five $\mathrm{C}-\mathrm{H}$...Cl. Each organic cation engages its hydrogen atoms bonded to $\mathrm{C}$ atoms in $\mathrm{C}-\mathrm{H}$...Cl hydrogen bonds. Accordingly, it is connected to anions and participates in the structure cohesion. The intermolecular distances $\mathrm{C}$...Cl vary from $3.712(3)$ to $3.858(2) \AA$ and the $\mathrm{C}-\mathrm{H} . . . \mathrm{Cl}$ angles range between $128(3)$ and $167(2)^{\circ}$.

\subsection{Spectroscopic studies}

The FT-IR and FT-Raman spectra of the title compound were measured for the powder sample at room temperature. Vibrational spectra are shown in Figures S1 and S2.

The frequencies observed in the infrared spectra at 2997 and $2987 \mathrm{~cm}^{-1}$ are assigned respectively to the $v_{\text {as }}$ and $v_{\mathrm{s}}$ of $\mathrm{CH}_{2}$, $\mathrm{CH}_{3}$ groups. The different modes of asymmetric $\left(\delta_{\text {as }}\right)$ and symmetric $\left(\delta_{\mathrm{s}}\right)$ deformation of the methyl groups are found at 
1385 and $1354 \mathrm{~cm}^{-1}$, respectively. A weak band which appeared at $1371 \mathrm{~cm}^{-1}$ is related to the C-C and C-N vibration [30,31]. Besides, sharp bands observed in IR at 1111, 1139 and in Raman at 1059, $1035 \mathrm{~cm}^{-1}$ are associated to $\mathrm{CH}_{3}$ and $\mathrm{CH}_{2}$ rocking vibration modes respectively. The band observed at $970 \mathrm{~cm}^{-1}$ in IR and $957 \mathrm{~cm}^{-1}$ in Raman were assigned to $v_{1}\left(\mathrm{NC}_{4}\right)$ stretching modes [32-34]. The deformation mode $v_{2}\left(\mathrm{NC}_{4}\right)$ appears at 765 and $753 \mathrm{~cm}^{-1}$ in IR and Raman spectrum, respectively. The splitting $v(\mathrm{C}-\mathrm{C}-\mathrm{C}-\mathrm{N})$ bending mode at $772 \mathrm{~cm}^{-1}$ may correspond to different conformers of the organic chains. The band observed at $478 \mathrm{~cm}^{-1}$ in Raman spectrum arises from the deformation vibration $v_{4}\left(\mathrm{NC}_{4}\right)$ of the TPCu entity.

Table 2. Selected bond lengths and bond angles of $\left[\left(\mathrm{CH}_{3} \mathrm{CH}_{2} \mathrm{CH}_{2}\right)_{4} \mathrm{~N}\right]_{2} \mathrm{Cu}_{2} \mathrm{Cl}_{6}$. Bond length, $\AA$

$\mathrm{Cu} 1-\mathrm{Cl} 2$

$\mathrm{Cu} 1-\mathrm{Cl} 3$

Cu1-Cl4

$\mathrm{Cl} 2-\mathrm{Cu} 1^{1}$

N1-C1

N1-C2

N1-C4

Bond angle,

$\mathrm{Cl} 2-\mathrm{Cu} 1-\mathrm{Cl} 2$

$\mathrm{Cl} 3-\mathrm{Cu} 1-\mathrm{Cl}{ }^{1}$

$\mathrm{Cl} 3-\mathrm{Cu} 1-\mathrm{Cl} 2$

$\mathrm{Cl} 3-\mathrm{Cu} 1-\mathrm{Cl} 4$

$\mathrm{Cl} 4-\mathrm{Cu} 1-\mathrm{Cl} 2$

Cl4-Cu1-Cl2

$\mathrm{Cu} 1-\mathrm{Cl} 2-\mathrm{Cu}{ }^{1}$

C1-N1-C2

C1-N1-C4

C2-N1-C4

C3-N1-C1

Torsion angle,

Cl21-Cu1-Cl2-Cu11 0.0

Cl3-Cu1-Cl2-Cu11 146.03(3)

Cl4-Cu1-Cl2-Cu1 ${ }^{1} \quad-96.44(5)$

N1-C1-C8-C10 177.9(2)

N1-C2-C6-C5 -172.1(2)

N1-C3-C7-C11 178.41(19)

N1-C4-C9-C12 176.4(2)

C1-N1-C2-C6 56.5(3)

C1-N1-C3-C7 178.5(2)

C1-N1-C4-C9 -58.1(3)

${ }^{1}$ Symmetry code: $1-x, 1-y, 1-z$

Table 3. Hydrogen bonds for the title compound.

\begin{tabular}{|c|c|c|c|c|}
\hline D-H...A* & $d(\mathrm{D}-\mathrm{H})(\AA)$ & $d(\mathrm{H} \ldots \mathrm{A})(\AA)$ & $d(\mathrm{D} \ldots \mathrm{A})(\AA)$ & $\angle \mathrm{D}-\mathrm{H} \ldots \mathrm{A}\left({ }^{\circ}\right)$ \\
\hline$\overline{\mathrm{C} 5-\mathrm{H} 5 \mathrm{C} \ldots \mathrm{Cl} 3^{i}}$ & 0.96 & 2.97 & $3.816(3)$ & 147.9 \\
\hline C11-H11A...Cl2ii & 0.96 & 2.95 & $3.821(3)$ & 151.5 \\
\hline C6-H7...Cl2iii & $1.05(4)$ & $2.97(5)$ & $3.712(3)$ & $128(3)$ \\
\hline C11-H11B...Cl2 & 0.96 & 2.92 & $3.832(3)$ & 158.6 \\
\hline $\mathrm{C} 1-\mathrm{H} 16 \ldots \mathrm{Cl} 3$ & $0.88(3)$ & $3.00(3)$ & $3.858(2)$ & $167(2)$ \\
\hline
\end{tabular}

* Symmetry codes: $i: x+1, y, z$; ii: $-x+2,-y+1,-z+1 ;$ iii: $-x+2,-y+2,-z+1$.

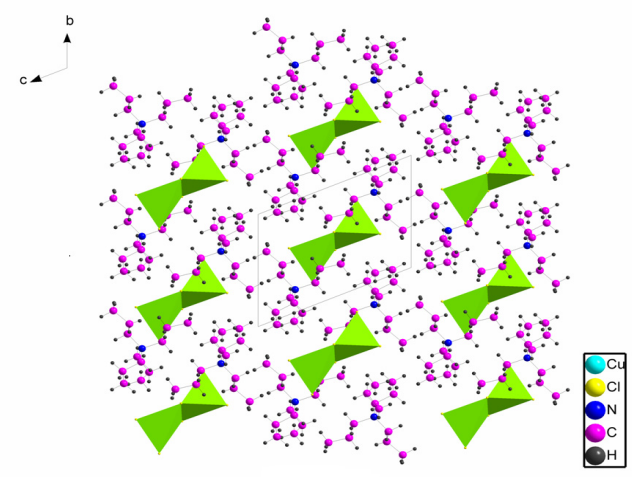

Figure 2. Projection along the a axis of the atomic arrangement of $\left[\left(\mathrm{CH}_{3} \mathrm{CH}_{2} \mathrm{CH}_{2}\right)_{4} \mathrm{~N}\right]_{2} \mathrm{Cu}_{2} \mathrm{Cl}_{6}$.
The Raman and IR active bands involving mainly the $\mathrm{Cu}_{2} \mathrm{Cl}_{6}$ vibration can be proposed by comparison with $\mathrm{Ga}_{2} \mathrm{Cl}_{6}$ [35]. The isolated inorganic entities exhibit $\mathrm{D}_{2 \mathrm{~h}}$ symmetry with 18 normal modes. In this framework, among the $10 \mathrm{Cu}_{2} \mathrm{Cl}_{6}$ Raman active modes, the 455, 311, 189, 98, 246 and $128 \mathrm{~cm}^{-1}$ lines can be assigned to the $4 \mathrm{Ag}\left(v_{1}-v_{4}\right)$ and $2 \mathrm{~B}_{1 \mathrm{~g}}\left(v_{6}, v_{7}\right)$, respectively. In the end, the $2 \mathrm{~B}_{2 \mathrm{~g}}\left(v_{11}, v_{12}\right)$ modes occur at $611 \mathrm{~cm}^{-1}$ of $v_{11}$ and $118 \mathrm{~cm}^{-1}$ of $v_{12}$. The bands observed at 197 and $373 \mathrm{~cm}^{-1}$ are assigned to the $B_{3 g}\left(v_{15}\right)$ and $B_{2 g}\left(v_{18}\right)$ modes, respectively. The $\mathrm{B}_{1 \mathrm{u}}\left(v_{8}\right), 2 \mathrm{~B}_{2 \mathrm{u}}\left(v_{13}, v_{14}\right)$ and $2 \mathrm{~B}_{3 \mathrm{u}}\left(v_{16}, v_{17}\right)$ modes are active in the IR spectra. Like in $\mathrm{Ga}_{2} \mathrm{Cl}_{6}$, only one $\left(v_{8}\right)$ over the $3 \mathrm{~B}_{1 \mathrm{u}}$ is observed. In the reported study only $v_{8}$ is observed. The $v_{1}, v_{8}$, $v_{11}$ and $v_{16}$ vibrations due to the $\mathrm{CuCl}_{2}$ stretching motions and their frequencies are higher than those of $v_{2}, v_{6}, v_{13}$ and $v_{17}$ that witch are mainly due to the vibrations of the bridging $\mathrm{Cu}_{2} \mathrm{Cl}_{6}$ groups.

\section{Conclusion}

Bis-tetrapropylammonium hexachlorodicuprate(II), $\left[\mathrm{N}\left(\mathrm{C}_{3} \mathrm{H}_{7}\right)_{4}\right]_{2} \mathrm{Cu}_{2} \mathrm{Cl}_{6}$, has been prepared and studied by single crystal X-ray diffraction and IR spectroscopy. The crystal packing of the salt $\left.\left[\mathrm{N}_{(} \mathrm{C}_{3} \mathrm{H}_{7}\right)_{4}\right]_{2} \mathrm{Cu}_{2} \mathrm{Cl}_{6}$ is based on inorganic $\mathrm{Cu}_{2} \mathrm{Cl}_{6}$ units surrounded by organic $\mathrm{N}\left(\mathrm{C}_{3} \mathrm{H}_{7}\right)_{4}$ entities into a triclinic crystal lattice symmetry.

\section{Acknowledgements}

Grateful thanks are expressed to Dr. Philippe Guionneau (Service Rayons X, ICMCB/CNRS Bordeaux) for the X-ray data collection.

\section{Supplementary material}

CCDC-857623 contains the supplementary crystallographic data for this paper. These data can be obtained free of charge via www.ccdc.cam.ac.uk/data request/cif, or by e-mailing data_request@ccdc.cam.ac.uk, or by contacting The Cambridge Crystallographic Data Centre, 12 Union Road, Cambridge CB2 1EZ, UK; fax: +44(0)1223-336033.

\section{References}

[1]. Braga, D.; Desiraju, G. R.; Miller, J. S.; Orpen, A. G.; Price, S. L. Cryst. Eng Commun. 2002, 4, 500-509.

[2]. Desiraju, G. R. Angew. Chem. Int. Ed. Engl. 1995, 34, 2311-2327.

[3]. Desiraju, G. R. J. Mol. Struct. 2003, 656, 5-15.

[4]. Mitzi, D. B. Prog. Inorg. Chem. 1999, 48, 1-12

[5]. Lacroix, P. G.; Clement, R.; Nakatani, K.; Delaire, J. A.; Zyss, J.; Ledoux, I. Science 1994, 263, 658-660.

[6]. De Zea Bermudez, V.; Carlos, L. D.; Duarte, M. C.; Silva, M. M.; Silva, C. J.; Smith, M. J.; Assunc, M.; Alcacer, L. J. Alloys Compd. 1998, 21, 275-277.

[7]. Carlos, L. D.; Sa Ferreira, R. A.; De Zea Bermudez, V.; Ribeiro, S. J. L. Adv. Funct. Mater. 2001, 11, 2111-115.

[8]. Kato, Y.; Ichii, D.; Ohashi, K.; Kunugita, H.; Ema, K.; Tanaka, K.; Takahashi, T.; Kondo, T. Solid State Commun. 2003, 128, 15-18.

[9]. El-Korashy, A.; Brik, M. G. Solid State Commun. 2005, 135, 298-303.

[10]. Ben Rhaiem, A.; Hlel, F.; Guidara, K.; Gargouri, M. J. Alloys Compd. 2008, 463, 440-445.

[11]. Cavellec, M. R.; Albinet, C.; Greneche, J. M.; Ferey, G. J. Mater. Chem. 2001, 11, 3166-3171.

[12]. Lach, G.; Laskowski, L.; Kityk, I. V.; Kapustianyk, V.; Rudyk, V.; Shchur, Y.; Tkaczyk, S.; Swiatek, J.; Piasecki, M. J. Non-Crystalline Solid. 2007, 353, 4353-4356.

[13]. Roman, P.; Sertucha, J.; Luque, A.; Lezama, L.; Rojo, T. Polyhedron 1996, 15, 1253-1262.

[14]. Angeloni, A.; Orpen, A. G. Chem. Commun. 2001, 26, 343-344

[15]. Guckian, K. M .; Schweitzer, B. A.; Ren, R. X. F.; Sheils, C. J.; Tahmassebi, D. C.; Kool, E. T. J. Am. Chem. Soc. 2000, 122, 2213-2222.

[16]. Janiak, C. J. Chem. Soc. Dalton Trans. 2000, 7, 3885-3896

[17]. Muller-Dethlefs, K.; Hobza, P. Chem. Rev. 2000, 100, 143-167.

[18]. Hiroyuki, H.; Mashiyama, H.; Koshiji, N. Acta Cryst. B. 1989, 45, 467 473.

[19]. Muller, E. A.; Cannon, R. J.; Sarjeant, A. N.; Ok, K. M.; Halasyamani, P. S.; Norquist, A. J. Cryst. Growth Des. 2005, 5, 1913-1917.

[20]. Nonius, Kappa CCD Program Software, Nonius BV, Delft, The Netherlands, 1998. 
[21]. Farrugia, L. J. J. Appl. Cystallogr. 1999, 32, 837-838.

[22]. Sheldrick, G. M. SHELXS-97 Programs for Crystal Solution. University of Gottingen, Germany, 1997.

[23]. Sheldrick, G. M. SHELXL-97 Programs for Crystal Structure Refinement. University of Gottingen, Germany, 1997.

[24]. Herringer, S. N.; Turnbull, M. M.; Landee, C. P.; Wikaira, J. L. J. Coord. Chem. 2009, 62, 863-875.

[25]. Luque, A.; Sertucha, J.; Castillo, O.; Roman, P. New. J. Chem. 2001, 25, 1208-1214.

[26]. Luque, A.; Sertucha, J.; Lezama, L.; Rojo, T.; Roman, P. J. Chem. Soc. Dalton Trans. 1997, 5, 847-854.

[27]. Al-Far, A. R. H.; Haddad, S. F. Acta Cryst. E 2008, 64, 689-690.

[28]. Haddad, S. F.; AlDamen, M. A.; Willett, R. D. Inorg. Chim. Acta. 2006, 359, 424-432.

[29]. Hafiz, A. A. Iran J. Chem. Soc. 2008, 5, 106-114.

[30]. Gosniowska, M.; Ciunik, Z.; Bator, G.; Jakubas, R.; Baran, J. J. Mol. Struct. 2000, 555, 243-255.

[31]. Karbowiak, M.; Hanuza, J.; Janczak, J.; Drozdzynski, J. J. Alloys Compd. 1995, 225, 338-343.

[32]. Hedderich, H. G.; Blom, C. E. J. Chem. Phys. 1989, 90, 4660-4663.

[33]. Hedderich, H. G.; Blom, C. E. J. Mol. Spectrosc. 1990, 140, 103-106.

[34]. Kirkwood, A. D.; Bier, K. D.; Thompson, J. K.; Haslett, T. L.; Hubber, A. S.; Moskovits, M. J. Phys. Chem. 1991, 95, 2644-2652.

[35]. Bellamy, L. J. The Infrared Spectra of Complex Molecules, $3^{\text {rd }}$ ed., Vol. I and II, Chapman and Hall, London, 1975, 1980. 